\title{
Prevalence and predictors of elder abuse in Mafikeng Local Municipality in South Africa
}

\author{
Paul Bigala' and Natal Ayiga ${ }^{2 *}$ \\ ${ }^{1}$ Population Research and Training Unit, North-West University (Mahikeng Campus), Private Bag \\ X2046, Mmabatho, 2735, South Africa. Tel: +27762288042; Email: Paulbigala@yahoo.com. \\ 2Population Research and Training Unit, North-West University (Mahikeng Campus), Private Bag \\ X2046, Mmabatho, 2735, South Africa.Tel: +27183892611; Email: Natal.Ayiga@nwu.ac.za; \\ nayiga1962@gmail.com.
}

\begin{abstract}
Elder abuse is widespread in South Africa and is a serious public health problem. This paper estimated the prevalence and identified the forms and predictors of elder abuse. The paper used cross-sectional data on 506 elderly people from Mafikeng Local Municipality in South Africa, and used the chi-square statistic and the logistic regression model to analyse the data. Overall $64.3 \%$ of men and $60.3 \%$ of women experienced elder abuse. Physical abuse was more common among men while emotional, financial and sexual abuses were more common among women. Having no working children, being currently single, living in elderly couple family, living in rural areas, having a poor self-perception of health and having a disability were significantly associated with elder abuse. We conclude that the prevalence of elder abuse is high and common, which calls for strategies to prevent the vice.
\end{abstract}

Keywords: Elderly; mistreatment; abuse; family structure; disability

\section{Résumé}

Les abus envers les personnes âgées est très répandue en Afrique du Sud et constitue un problème grave de santé publique. Cette étude a évalué la prévalence des abus infliges aux personnes âgées, l'identification de leurs formes et les facteurs prédicateur. Cet article a utilisé des données transversales sur 506 personnes âgées de la municipalité de Mahikeng en Afrique du Sud. La méthode statistique chi-carré et le modèle de régression logistique ont été utilisés pour analyser les données. En générale $64,3 \%$ d'hommes et $60,3 \%$ de femmes ont été victimes des violences. La violence physique est plus fréquente chez les hommes tandis que les abus émotionnels, financiers et sexuels ont été plus fréquents chez les femmes. Le manque d'enfants avec un travail consistant, vivant seuls ou en couples âgés, vivant en zones rurales, et la mauvaise perception de l'état de leur santé et certaines infirmités ou handicapes chez les personnes âgées étaient significativement associés aux abus des personnes âgées. En conclusion la prévalence des abus des personnes âgées est élevé et courant en Afrique du Sud. Ceci appelle à des stratégies de prévention pour prévenir ce vice.

Mots clé: personnes âgées; mauvais traitements; abus; la structure familiale; le handicap

\footnotetext{
* Corresponding Author 


\section{Introduction}

Elder abuse is increasingly becoming a matter of global concern in both developed and developing countries. The World Health Organization (WHO) defined elder abuse as "a single or repeated act or lack of appropriate action within any relationship where there is expectation of trust, which causes harm or distress or is likely to cause harm or distress to an older person" (WHO 2008). The United Nations Population Division (2002) defined the elderly as people aged 60 years or older and estimated that by 2025 , their global population will reach 1.2 billion, up from 542 million in 1995.

The population of the elderly has consistently increased in sub-Saharan Africa in the recent past, which represents a major shift in population structure in this region. Although this is an indication of progress, it has been overshadowed by the increasing prevalence of elder abuse (Mba 2007), which is a departure from the tradition of respect and reverence elderly people enjoyed in most African societies. The increasing prevalence of elder abuse is a reflection of the changing social and economic environment occasioned by the process of modernization and urbanization which have eroded the traditional social support system leading to neglect, exclusion and abuse (Knodel \& Ofstedal 2005).

In this paper we examined the prevalence of elder abuse in the North West province where the magnitude of the phenomenon and its predictors are not well known. Specifically we estimated the magnitude of elder abuse, identified the main forms and the significant predictors of elder abuse. The importance of the study is premised on the understanding that elder abuse is widespread in subSaharan Africa and in South Africa in particular, and identifying the predictors of elder abuse is central in stemming the vice.

\section{Literature Review:}

Previous studies identified four main forms of elder abuse including physical abuse which refers to any conduct that violates the physical integrity of an older person; sexual abuse which is the conduct that violates the sexual integrity of an older person; and psychological abuse which refers to any form of degrading or humiliating conduct such as instilling fear, name calling and isolation of an older person (MacNeil et al. 2010. Other forms of elder abuse are economic or financial abuse which refers to the illegal taking, misuse, or concealment of funds, property or assets or intentional and unintentional abandonment or denial of support to an older person by people expected to provide such support (Mudiare 20I3).

Knowledge of the prevalence of elder abuse and its predictors in sub-Saharan Africa is still low mostly because of the stigma associated with the phenomenon and its hidden nature and lack of consensus on the age at which old age begins between different societies (Ferreira \& Lindgren 2008). Nonetheless there is research evidence showing that the main forms of elder abuse in subSaharan Africa are physical abuse exacerbated by cultural beliefs and accusations of witchcraft, probably as a result of the physical characteristics of the elderly such as their wrinkled skin, gnarled hands and yellow eyes (Phakathi 20II), and economic abuse characterized by deprivation of property including land, especially for women often leading to destitution as property is inherited by males (Ferreira \& Lindgren 2008). There is a strong gender difference in the form and perpetrators of elder abuse. While men, including the children of the elderly, are the main perpetrators of physical, emotional and financial abuse, women perpetrate mostly emotional abuse (Dunlop et al. 2008).

Elder abuse has serious public health outcomes. Previous studies found that elder abuse is a significant predictor of suicidal ideation (Wu et al. 2013); injury, pain, and decreased quality of life; psychological problems including depression, anxiety and post-traumatic stress and death due to neglect and loneliness (Pillemer \& Prescott 1989). Elder abuse, its signs and symptoms can be confused with changes brought about by ageing and therefore can easily be misdiagnosed (Fisher et al. 2010). Although there are existing laws that guarantee the rights of the elderly and freedom from abuse, previous studies have reported that the prevalence of elder abuse is increasing in sub-Saharan Africa (Cadmus \& Owoaje 20I2).

In South Africa, there is increasing evidence indicating that elder abuse is becoming widespread and the main forms of elder abuse are physical, financial, emotional abuses (Makiwane \& Kwizera, 2007) and marginalization, disrespect, exploitation and violence (Ferreira \& Lindgren 2008). Also increasing in magnitude is the sexual abuse of elderly women, and because of its nature and taboos associated with it, sexual abuse is stigmatized and is 
a source of fear and shame and rarely reported (Phakathi 20I I).

Some of the main drivers of elder abuse in South Africa include poverty due to the rampant unemployment, which has caused the abandonment, neglect and deprivation of the elderly (Mba 2007), and the unprecedented level of poverty due to unequal distribution of and access to resources perpetuated by apartheid (Reddy 2002); changes in the traditional norms of respect and care practices "Ubuntu", which in Zulu refers to "a person is person through other persons" (Shutte 1993:46), has been eroded by migration and urbanisation leading to the neglect of the elderly; inheritance laws regarding property which do not favour the elderly, especially women, leading to economic and financial abuse (WHO 2002); and alcohol and drug abuse induced breakdown of social control at family and community level (Ferreira \& Lindgren 2008). The growing prevalence of elder abuse has raised the urgency of investigating this phenomenon. The main objectives of this paper are therefore to estimate the prevalence of elder abuse and identify its forms and predictors in the Mafikeng Local Municipality of the North West Province, where the extent of the phenomenon is not well known.

\section{Data and Method:}

\section{Data}

This paper used cross-sectional data collected from Mafikeng Local Municipality in Modiri-Molema district in the North West Province of South Africa in 2008. The North West Province is one of the provinces in South Africa where the population of the elderly increased slightly from $7.4 \%$ in 2001 to $7.5 \%$ in 2007 and to nearly $8 \%$ in 2010 . Of the 29I,527 people in the Mafikeng Local Municipality alone, 20,963 were elderly people, representing $7.2 \%$ of the total population of the Municipality in 2010 (Statistics South Africa 20 I I).

The sample of the study was drawn by use of the multi-stage sampling design. The first stage involved the selection of one urban and one rural ward out of 8 urban and 20 rural wards respectively and in the second stage, a total of $1 \mathrm{I}$ enumeration areas, 4 from urban and 7 from rural wards were selected by use of the simple random sampling method. In the third stage, 560 households, of which 124 and 315 households were in urban and rural wards respectively, were selected by use of the systematic random sampling method. From selected households, a total of 506 people aged 60 years or older ( 171 men representing $33.8 \%$ and 335 women representing $66.2 \%$ ) were successfully interviewed.

Ethical approval was obtained from the Faculty of Human and Social Sciences Graduate and Research Committee of the North-West University. Permission to conduct the study was obtained from the Provincial Department of Social Development, councillors and chiefs in the wards in which the study was conducted. Informed consent was obtained from each elderly respondent who was informed of the confidentiality and anonymity of the data collected. They were also assured of their right to refuse to participate in the study without consequences.

\section{Variable measures}

In this paper the dependent variable was elder abuse status which was obtained by asking the elderly whether or not they perceived they were ever abused. Those who reported they were abused were then asked specific questions targeting the experience of physical, sexual, financial and emotional abuses. A composite variable "ever experienced elder abuse?" was then constructed as the dependent variable using the four forms of elder abuse. The variable was recoded "I" if elder abuse ever occurred and " 0 " if otherwise.

The independent variables comprised of sociodemographic and health variables. The demographic variables analysed were age categorized as "60-69", "70-79" and " 80 " years or older; and number of children surviving categorised as "none and at least one child. Socioeconomic variables included were number of working children categorized as "none" and at least one; marital status categorized as currently in union and currently single (widowed, divorced and never in union); place of residence categorized as rural and urban; and family structure categorized as elderly couple family, single elder family and extended family. Other socioeconomic variables analysed were level of education categorized as no education, primary and higher education (secondary and tertiary); main source of income categorized as salaries/wages, pension and others (own children and other relatives); and main care provider categorized as spouse, self and others (own children and other relatives). Regarding health variables, perceived current status of health categorized as poor and good; and disability status categorized as having a disability and not having a 
disability were analysed. These variables were hypothesised to significantly influence elder abuse in the Mafikeng Local Municipality.

\section{Statistical analysis}

Data analysis was done in three stages by use of SPSS version 21 . In the first stage, descriptive statistics of the elderly was performed to describe the demographic, socioeconomic and health profiles of the elderly and the results were disaggregated by gender and presented in frequency distributions. In the second stage the Pearson's chi-square statistic was used to test the association between forms of elder abuse and gender and experience of elder abuse and the socio-demographic and health characteristics of the elderly. The analysis was disaggregated by gender and tested at the $95 \%$ confidence interval $(p<0.05)$. In the third stage, which was the multivariate analysis, we used the logistic regression model to identify the significant predictors of elder abuse by use of two models, one for men and another for women. In doing so, only variables which were significantly associated with elder abuse at the bivariate analysis were included in both models. A goodness of fit test were performed and the results were significant at $p<0.000$ I indicating that the binary regression models were good fits. The use of this form of regression was chosen because the outcome variable was dichotomous with "I" indicating that elder abuse occurred and " 0 " if otherwise (Elis and Wang 1992).

\section{Results}

\section{Socio-demographic and health profile of the study sample}

The socio-demographic and health profiles of the elderly presented in Table I shows that the median age of the men was $7 \mathrm{I}(\mathrm{SD}=7.3)$ and that of the women was $72(S D=9.2)$. The majority of the men and women were in the 60-69 year age group. The mean number of surviving children was 2.9
$(S D=2.6)$ for men and $3.0(S D=2.8)$ for women and the majority of the men and the women had at least one surviving child. Only $32.2 \%$ and $11.3 \%$ of the men and the women respectively had no surviving children. The men and the women had only 2.2 $(\mathrm{SD}=1.4)$ and $2.5(\mathrm{SD}=1.6)$ working children respectively and nearly 5 in 10 and 6 in 10 men and women respectively had at least one working child.

Most of the elderly $(74.7 \%)$, mostly women were single and $32 \%$ of the men and $22 \%$ of the women were in a marital union. The majority of men and women were in the single elder family followed by extended family respectively. Nearly 5 in 10 of the men and 6 in 10 of the women depended on self as the main care provider and only $I$ in 10 men and nearly 4 in 10 women depended on spouses as the main care provider. Table I also shows that the majority, men and women alike, had no formal education, resided in rural areas and received pension as their main source of income; and about 7 in 10 and nearly 8 in 10 of the men and women perceived their current health status as good and had no disability respectively.

\section{Prevalence and forms of elder abuse}

Overall, the prevalence of elder abuse in the Mafikeng Local Municipality was found to be high. Table 2 shows that although the forms of abuses varied by gender, 6 in 10 men and women alike reported ever experiencing at least one form of abuse. Nearly 3 in 10 men and women alike reported they have ever experienced financial abuse and nearly 2 in 10 men and at least $\mathrm{I}$ in 10 women experienced emotional abuse. More men (22.8\%) than women $(8.1 \%)$ experienced physical abuse and only women (8.4\%) experienced sexual abuse. However, only physical and sexual abuses were statistically significantly different between the gender at $\mathrm{p}<0.05$.

Table I Socio-demographic and health characteristics of the elderly men and women

\begin{tabular}{lllllll}
\hline Characteristic & \multicolumn{2}{c}{ Males } & Females & \multicolumn{2}{c}{ Total } \\
\cline { 2 - 7 } & Number & $\%$ & Number & $\%$ & Number & $\%$ \\
\hline Age & 86 & 40.3 & 175 & 52.2 & 261 & 51.6 \\
$60-69$ & 58 & 33.9 & 90 & 26.9 & 148 & 19.2 \\
$70-79$ & 27 & 15.8 & 70 & 20.9 & 97 & 19.2 \\
$80+$ & & & & &
\end{tabular}




\begin{tabular}{lllllll}
\hline $\begin{array}{l}\text { Median age } \\
\text { Number of surviving }\end{array}$ & 71 & $\mathrm{SD}=7.3$ & 72 & $\mathrm{SD}=9.2$ & \\
$\begin{array}{l}\text { children } \\
\text { None }\end{array}$ & 55 & 32.2 & 38 & 11.3 & 93 & 18.4 \\
At least one & $\mathrm{II}$ & 67.8 & 297 & 88.7 & 413 & 81.6 \\
Mean CEB & 2.9 & $\mathrm{SD}=2.6$ & 3.0 & $\mathrm{SD}=2.8$ & &
\end{tabular}

Table I Continue

\begin{tabular}{|c|c|c|c|}
\hline Characteristic & Males & Females & Total \\
\hline & Number $\%$ & Number & Number \\
\hline
\end{tabular}

\section{Current marital Status}

Currently in union Currently 54

$\begin{array}{ll}\text { single } & 117\end{array}$

$31.6 \quad 74$

22.1

128

25.3

Family structure

Elderly couple family

Single elder family

46

26.9

92

27.5

138

27.3

Extended family

68

39.8

114

34.0

182

36.0

57

33.3

129

38.5

186

36.7

Main care provider

Spouse

Self

Others

Level of Education

No

Primary

Higher

Place of Residence

Rural

Urban

131

40

76.6

$24 I$

94

23.4

7.6

24

80.1

266

12.1

45

Self-perception of health

Poor

Good
21

13

137

50

121
29.2

70.8
13

210

112

144

134

18.1 57

3.9

32

6.3

62.7

295

58.3

33.4

179

35.4

43.0

226

44.7

40.0

192

37.9

17.0

88

17.4 


\section{Disability Status}

Has a disability

Ha no disability

133

22.2

77.8

59

276

17.6

97

19.2

\section{Ever experienced elder}

\section{abuse?}

$\begin{array}{lll}\text { Yes } & 110 & 64.3 \\ \text { Never } & 61 & 35.7 \\ \text { Total } & 171 & 100.0\end{array}$

\section{Differentials of elderly abuse}

Differentials of elder abuse by socio-demographic and health characteristics are presented in Table 3 by gender. The table shows that more men $(70.7 \%)$ with at least one surviving child and more women (86.8\%) with no surviving children experienced elder abuse. More men (79.3\%) with at least one working child and more women $(69.7 \%)$ with no working children also experienced elder abuse and elder abuse was significantly associated with the number of surviving and working children. The table further shows that 7 in 10 men and slightly more than 6 in 10 women who were single experienced elder abuse; and nearly 9 in 10 men and over 7 in 10 women in elderly couple

$\begin{array}{llll}202 & 60.3 & 312 & 61.7\end{array}$

$\begin{array}{llll}133 & 39.7 & 194 & 38.3\end{array}$

$\begin{array}{llll}335 & 100.0 & 506 & 100.0\end{array}$

family experienced elder abuse compared to about 5 in 10 men and women in extended families, and elder abuse was significantly associated with marital status and family structure. Additionally, elder abuse was higher in rural than urban areas for women; among men and women who reported their spouses were the main care provider; and among men and women (8 in 10) who had a poor self-perception of health. Conversely, the majority of the men and women alike (8 in 10) who had no disability, experienced elder abuse. The results show that place of residence, main care provider, self-perception of health and disability statuses were significantly associated with elder abuse.

Table 2 Distribution of the elderly by forms of elder abuse and gender

\begin{tabular}{lcccccc}
\hline \multirow{2}{*}{$\begin{array}{l}\text { Forms of elder } \\
\text { abuse }\end{array}$} & \multicolumn{2}{c}{ Males } & \multicolumn{2}{c}{ Females } & $\mathbf{X}^{2}$ & \multirow{2}{*}{ Total } \\
\cline { 2 - 5 } & \multicolumn{2}{c}{ Experience elder abuse } & \multicolumn{2}{c}{ Experience elder abuse } & & \\
\cline { 2 - 5 } & Yes & No & Yes & No & & \\
\hline Physical & $22.8(39)$ & $77.2(132)$ & $8.1(27)$ & $91.9(308)$ & $21.7 \mid * * * * *$ & 100.0 \\
Sexual & $0(0)$ & $100.0(17 I)$ & $8.4(28)$ & $91.6(307)$ & $15.13^{* * * * *}$ & 100.0 \\
Financial & $28.5(4 I)$ & $76.0(130)$ & $30.7(103)$ & $69.3(232)$ & 2.55 & 100.0 \\
Emotional & $17.5(30)$ & $82.5(14 I)$ & $13.1(44)$ & $86.9(291)$ & 1.76 & 100.0 \\
\hline Total & $64.3(110)$ & $35.7(61)$ & $60.3(202)$ & $39.7(133)$ & & 506
\end{tabular}

$\mathrm{n}$ in parentheses; Level of significance: ${ }^{*}=\mathrm{p}<0.05$; ${ }^{* *}=\mathrm{p}<0.0 \mathrm{I}$; $* * *=\mathrm{p}<0.00 \mathrm{I}$; ${ }^{* * * *}=\mathrm{p}<0.000 \mathrm{I}$

\section{Predictors of elderly abuse}

The main predictors of elder abuse among men and women are presented in Model I for men and Model 2 for women (Table 4). Model I shows that elder abuse was significantly more likely and increased by $3.29(p<0.00 \mathrm{I})$ times, $3.82(p<0.00 \mathrm{I})$ times and $4.74(p<0.01)$ times among men who had at least one working child, currently single men and men in elderly couple families respectively. Additionally, men who had a poor self-perception of health $(O R=3.19, p<0.05)$ and had a disability $(O R=2.59, p<0.05)$ were significantly more likely to have experienced elder abuse. Conversely, elder abuse was significantly less likely among men by $61 \%$ if they had at least one surviving child.

Regarding the women, results presented in Model 2 show that elder abuse was significantly 
more likely if women had no surviving children (4.38, $\mathrm{p}<000 \mathrm{I})$ and had no working children (2.97, $\mathrm{p}<0.05)$. Additionally, women living in elderly couple families and in rural areas were 3.68 $(p<0.00 \mathrm{I})$ and $5.88(p<0.000 \mathrm{I})$ times respectively significantly more likely to have experienced elder abuse. Women were also more likely to have experienced elder abuse if they had a poor selfperception of health $(O R=2.95, p<0.0001)$ and had a disability $(O R=3.6 \mathrm{I}, \mathrm{p}<0.0 \mathrm{I})$.

Table 3 Differentials of men and women by experience of elder abused by socio-demographic and health characteristics

\begin{tabular}{|c|c|c|c|c|c|c|}
\hline \multirow[t]{3}{*}{ Characteristic } & \multicolumn{6}{|c|}{ Ever experienced elder abuse? } \\
\hline & \multicolumn{2}{|c|}{ Men } & \multicolumn{4}{|c|}{ Women } \\
\hline & Yes & No & $x^{2}$ & Yes & No & $\mathrm{X}^{2}$ \\
\hline \multicolumn{7}{|l|}{ Age } \\
\hline $60-69$ & $60.5(52)$ & $39.5(34)$ & 2.53 & $57.1(100)$ & $42.9(75)$ & 1.56 \\
\hline 70-79 & $63.8(37)$ & $36.2(2 I)$ & & $64.4(58)$ & $35.6(32)$ & \\
\hline $80+$ & $77.8(2 \mathrm{I})$ & $22.2(6)$ & & $62.9(44)$ & $37.1(26)$ & \\
\hline \multicolumn{7}{|c|}{ Number of surviving } \\
\hline \multicolumn{7}{|l|}{ children } \\
\hline None & $50.9(28)$ & $49.1(27)$ & $6.36 *$ & $86.8(33)$ & $13.2(5)$ & $|2.6| * * * *$ \\
\hline At least one & $70.7(82)$ & $29.3(34)$ & & $56.9(169)$ & $43.1(128)$ & \\
\hline \multicolumn{7}{|c|}{ Number of working } \\
\hline \multicolumn{7}{|l|}{ children } \\
\hline None & $79.3(65)$ & $20.7(17)$ & $15.33 * * * *$ & $54.9(117)$ & $45.1(96)$ & $7.04 * *$ \\
\hline At least one & $50.6(45)$ & $49.4(44)$ & & $69.7(85)$ & $30.3(37)$ & \\
\hline \multicolumn{7}{|l|}{ Marital Status } \\
\hline Currently in union & $42.6(23)$ & $57.4(3 \mathrm{I})$ & $16.25 * * * * *$ & $50.0(37)$ & $50.0(37)$ & $4.21 *$ \\
\hline Currently single & $74.4(87)$ & $25.6(30)$ & & $63.2(165)$ & $36.8(96)$ & \\
\hline \multicolumn{7}{|l|}{ Family structure } \\
\hline Elder couple family & $87.0(40)$ & $13.0(6)$ & $15.24 * * * *$ & $70.7(65)$ & $29.3(27)$ & $|2.2|^{* * * *}$ \\
\hline Single elder family & $60.3(4 I)$ & $39.7(27)$ & & $64.9(74)$ & $35.1(40)$ & \\
\hline Extended family & $50.9(29)$ & 49.1 (28) & & $48.8(63)$ & $51.2(66)$ & \\
\hline \multicolumn{7}{|l|}{ Main care provider } \\
\hline Spouses & $89.5(17)$ & $10.5(2)$ & $8.79 * *$ & $69.2(9)$ & $30.8(4)$ & 1.01 \\
\hline Self & $67.1(57)$ & $32.9(28)$ & & $61.4(129)$ & $38.6(8 I)$ & \\
\hline Others & $53.7(36)$ & $46.3(31)$ & & $57.1(64)$ & $42.9(48)$ & \\
\hline
\end{tabular}


African Population Studies, Vol. 28, No. I, April 2014

Table 3

Continue

\begin{tabular}{|c|c|c|c|c|c|c|}
\hline \multirow[t]{3}{*}{ Characteristic } & \multicolumn{6}{|c|}{ Ever experienced elder abuse? } \\
\hline & \multicolumn{3}{|c|}{ Men } & \multicolumn{3}{|c|}{ Women } \\
\hline & Yes & No & $X^{2}$ & Yes & No & $x^{2}$ \\
\hline \multicolumn{7}{|c|}{ Level of Education } \\
\hline No & $57.3(47)$ & $42.7(35)$ & 5.57 & $55.6(80)$ & $44.4(64)$ & 2.39 \\
\hline Primary & $72.4(42)$ & $27.6(16)$ & & $64.2(86)$ & $35.8(48)$ & \\
\hline Secondary/Higher & $67.7(2 \mathrm{I})$ & $32.3(10)$ & & $63.2(36)$ & $36.8(2 I)$ & \\
\hline \multicolumn{7}{|c|}{ Place of Residence } \\
\hline Urban & $64.1(84)$ & $35.9(47)$ & 0.10 & $65.6(158)$ & $34.4(83)$ & $9.393 * * *$ \\
\hline Rural & $65.0(26)$ & $35.0(14)$ & & $46.8(44)$ & $53.2(50)$ & \\
\hline \multirow{2}{*}{\multicolumn{7}{|c|}{$\begin{array}{l}\text { Main source of } \\
\text { income }\end{array}$}} \\
\hline & & & & & & \\
\hline Salaries/wages & $76.9(10)$ & $23.1(3)$ & 3.56 & $65.5(15)$ & $37.5(9)$ & 5.28 \\
\hline Pension & $65.7(90)$ & $34.3(47)$ & & $57.5(153)$ & $42.5(113)$ & \\
\hline Others & $47.6(10)$ & $52.4(\mathrm{II})$ & & $75.6(34)$ & $24.4(\mathrm{II})$ & \\
\hline \multirow{2}{*}{\multicolumn{7}{|c|}{$\begin{array}{l}\text { Self-perception of } \\
\text { health status }\end{array}$}} \\
\hline & & & & & & \\
\hline Poor & $83.5(101)$ & $16.3(20)$ & I4.46**** & $90.2(55)$ & $9.8(6)$ & $27.79 * * * *$ \\
\hline Good & $55.4(28)$ & $14.0(22)$ & & $53.6(147)$ & $46.4(127)$ & \\
\hline \multicolumn{7}{|l|}{ Disability Status } \\
\hline Yes & $81.6(31)$ & $18.4(7)$ & $6.34 * * *$ & $79.7(47)$ & $20.3(12)$ & $\mid \mathrm{I} .21 * * * * *$ \\
\hline No & $59.4(79)$ & $40.6(54)$ & & $56.2(155)$ & $43.8(121)$ & \\
\hline Total & $64.3(110)$ & $35.7(6 \mathrm{I})$ & & $60.3(202)$ & $39.7(133)$ & \\
\hline
\end{tabular}

Table 4 Logistic regression model showing Odds Ratios predicting the occurrence of elder abuse by gender

\begin{tabular}{|c|c|c|c|c|}
\hline & \multicolumn{2}{|c|}{ Model I } & \multicolumn{2}{|r|}{ Model 2} \\
\hline & \multicolumn{2}{|c|}{ Male } & \multicolumn{2}{|r|}{ Female } \\
\hline & OR & IC & OR & IC \\
\hline \multicolumn{5}{|c|}{ Number of children surviving } \\
\hline None & 1.00 & $(0.17-0.89)$ & $4.38 * * *$ & $(1.5 I-12.69)$ \\
\hline At least one ${ }^{\circledR}$ & $0.39 *$ & & 1.00 & \\
\hline \multicolumn{5}{|c|}{ Number of working children } \\
\hline None & $3.29 * * *$ & $(1.45-7.44)$ & $2.97 * * *$ & $(1.65-5.36)$ \\
\hline At least one ${ }^{\circledR}$ & 1.00 & $(0.57-8.09)$ & 1.00 & \\
\hline \multicolumn{5}{|c|}{ Current marital status } \\
\hline Currently in union ${ }^{\circledR}$ & 1.00 & & 1.00 & \\
\hline Currently single & $3.82 * * *$ & $(1.63-8.93)$ & 1.59 & $(0.84-3.0 I)$ \\
\hline
\end{tabular}


Table 4 Continue

\section{Family structure}

Elder couple family

Single elder family

Extended family ${ }^{\circledR}$

Place of residence

Rural

Urban ${ }^{\circledR}$

\section{Main care provider}

Spouse $\quad 3.28$

Self $\quad 1.42$

Others ${ }^{\circledR}$

Self-perception of health status

Poor

3.19*

Good ${ }^{\circledR}$

1.00

Disability Status

Yes

$2.59 *$

No ${ }^{\circledR}$
1.00

$\begin{array}{lll}4.74 * * & (1.45-15.55) & 3.68 * * * \\ 1.31 & (0.53-3.24) & 1.59 \\ 1.00 & & 1.00\end{array}$

$5.88 * * * *$

1.00

(0.59- 18.28)

(0.58-3.45)

.


Ofstedal 2005) and the community fills the gap of care responsibility mostly because the elderly are regarded as the repositories of knowledge and custodians of culture, which affords them respect and reverence. The networks of relationships shield the elderly from emotional abuse, loneliness and poverty particularly in rural communities where the majority of Africa's and South Africa's elderly people live (Stloukal 200I). This sharply contrasts with the situation of the elderly in urban communities where the elderly are susceptible to a life without close family leading to the risk of neglect, poverty and destitution (Tibaijuka 2008) and loneliness and sometimes physical violence in institutional care facilities (Weeks et al. 2008).

The lower risk of elder abuse among men who have surviving children suggests that the men received care and support from their children, which is consistent with the African cultural norm which requires children to care for their aging parents. Conversely, the greater likelihood of elder abuse among women with no surviving children could be attributed to the high mortality rates of the economically and socially productive young adults due to the HIV/AIDS epidemic, (Urassa et al. 1997), which also stigmatises HIV/AIDS affected families (Ayiga et al. 2012), and is itself a form of abuse. This view is consistent with the finding in other Southern African countries where the elderly have been hard hit by economic deprivation resulting from the death of care givers from HIV/AIDS (Kimuna 2002).

Rural-urban migration could have also contributed to elderly abuse, especially for women. South Africa has experienced large scale migration of young adults, especially men, from rural to urban areas in the post-apartheid period in search of employment and better life. This appears to have had negative impacts on the care of aging people in rural communities by weakening the traditional "Ubuntu" support and care system, which was an important social security system providing care and support for vulnerable members of society including elderly people. This is consistent with a previous study which found that migration increases vulnerability of the elderly to loneliness and poverty (Kakwani \& Subbrarao 2008; Ogwumike \& Aboderin 2005). Additionally, the dependence of many families on elderly pensions in the post-apartheid South Africa also suggests that some of the elderly could have been victims of pension confiscation by their dependent adult unemployed children and fraud by the so called "loan sharks". Pensioners are also assuming the dual roles of care and breadwinner for the family by providing care for their adult children, grandchildren and contributing to their expenses whenever they are sick (Ferreira 2008) thereby increasing their vulnerability to social and economic hardships. Elder abuse may also be perpetrated by their own sons and daughters in-law due to the changing social contract between generations, in which the younger generation regard old parents as a burden, leading to neglect, loneliness and destitution (Chao-Yin 2010).

The finding that elder abuse is more likely among men and women who had a disability or a poor selfperception of health is not surprising as they are more likely than other people without disabilities and in good health to be neglected and financially and emotionally maltreated because of their dependence on other people for most daily services including mundane ones (Tatara 1997). Conversely, self-perception of poor health could also be an indication that elderly people are being abused or are in fear of being abused or becoming victims of crime, which is consistent with the high rate of crime in South Africa, which impedes the mobility and participation of the elderly in ordinary life activities leading to psychological problems such as stress and depression. A previous study found that old people who have been physically and emotionally abused are more likely to be physically ill and emotionally impaired than non-abused people (Olofsson et al. 2012).

\section{Conclusions}

This study concludes that the prevalence of elder abuse in Mafikeng Local Municipality is high. Although elder abuse is common among men and women, it is more prevalent among men. The most common forms of abuse were physical, financial and emotional abuses. The main predictors of elder abuse were found to be having no surviving children, having no working children, being currently single, living in elderly couple family, living in rural areas, having a poor self-perception of health and having a disability. These findings require action to prevent elder abuse from further escalating, as the above forms of abuses are generally common in South Africa among vulnerable populations.

Although the study has identified some significant predictors of elder abuse, there are some limitations which need mentioning. Firstly, the use of crosssectional data makes the temporality of elder abuse, its forms and predictors unknown since elder abuse 
and its predictors are dynamic. Secondly, definitional limitations regarding forms of elder abuse may have affected the quality of reporting on whether or not elder abuse was experienced. Thirdly, the relatively small sample may have affected the estimation of some of the forms of elder abuse and their predictors. Nevertheless we consider this study as an important step in understanding and addressing elder abuse in Mafikeng Local Municipality in particular and North West province in general.

\section{Acknowledgement}

The authors are grateful to the School of Research and Graduate Studies at North-West University Mafikeng Campus for the financial support towards collecting the data used in this study. We also extend our gratitude to all the elderly respondents who participated in the study and the research assistants who collected the data.

\section{References}

Ayiga, N., Nambooze, H., Nalugo, S., Kaye, D \& Katamba, A 2013. "The impact of HIV/AIDS stigma on HIV counseling and testing in a high HIV prevalence population in Uganda." African Health Sciences I3, (2): 278-286.

Cadmus, E.O \& Owoaje, E.T 20I2. "Prevalence and correlates of elder abuse among older women in rural and urban communities in South Western Nigeria." Health Care Women International 33, (I0):973-984.

Chao-Yin, L.R.N 2010. "Caring for older adults: The parables in Confucian texts." Nursing Science Quarterly 23, (3):266-267.

Dunlop, B.D, Rothman, M.D, Condon, K., Herbert, K \& Martinez, I 200I. "Elder abuse, risk factors and use of case data to improve policy and practise." Journal of Elder Abuse and Neglect 12, (3-4):95-122.

Elisa, T.L \& Wang, J (1992): Statistical methods for survival data analyses. 2nd ed. New York, NY: John Willy \& Sons, Inc.

Ferreira, M 2008. "Elder abuse in Africa: what policy and legal provisions are there to address the violence?" Journal of Elder Abuse and neglect 16, (2): 17-32.

Ferreira, M \& Lindgren, P 2008. "Elder abuse and neglect in South Africa: A case of marginalisation, disrespect, exploitation and violence." Journal of Elder Abuse and Neglect 20, (2):9I-I07.

Fisher, B., Zink, T \& Regan, S 20I0. "Abuses against older women: prevalence and health effects."
Journal of Interpersonal Violence 26, (2): 254258.

Kakawani, N \& Subbrarao, K 2008. "Poverty among the elderly in sub-Saharan Africa and the role of social pensions." Journal of development Studies 43, (6):987-1008.

Kimuna, S 2002. "Living arrangements and conditions of older people in Zimbabwe." African Population Studies 20, (2): 143-163.

Knodel, J \& Ofstedal, M.B 2005. Patterns and determinants of living arrangements-". In: A.l. Hermalin \& A. Arbor (eds), The wellbeing of the elderly in Asia, University of Michigan Press, pp. 143-185.

Makiwane, M \& Kwizera, S.A 2006. "An investigation of quality of life of the elderly in South Africa, with specific reference to Mpumalanga province." Applied Research in Quality of Life I:297-3 I3.

MacNeil, G., Kosberg, J.I., Durkin, D., Dooley, W.K., DeCoster, J \& Williamson, G.M 2010. "Caregiver mental health and potentially harmful caregiving behaviour: The central role of caregiver anger." Gerontologist 50:76-86.

Mba, C.J 2007. "Elder abuse in parts of Africa and the way forward." Journal of Gerontology 6, (4):230-235.

Mudiare, P.E.U 2013. "Abuse of the aged in Nigeria: Elders also cry." American International Journal of Contemporary Research 3, (9):79-87.

Ogwumike, F.O \& Aboderin, I 2005. "Exploring the link between old age and poverty in Anglophone West Africa: Evidence from Nigeria and Ghana." Generations Review 15:7-15.

Olofsson, N., Lindqvist, K \& Danielsson, I 2012. "Fear of crime and psychological and physical abuse associated with ill health in a Swedish population aged 65-84 years." Public Health 126, (4):358-364.

Phakathi, N 201I. Exploring elder abuse among clinic attendees in selected Durban hospitals. Master dissertation, Dept. of Nursing, University of KwaZulu Natal.

Pillemer, K.A \& Prescott, D 1989. "Psychological effects of elder abuse: a research note." Journal of Elder Abuse and Neglect I, (I):65-74.

Reddy, P. 2002. The plight of older persons in South Africa. In: UNFPA (United Nations Population Fund), Situation and Voices: The Older poor and 
Excluded in South Africa and India. United Nations: New York, pp. 19-58.

Shutte, A (1993): Philosophy for Africa. Rondebosch, South Africa: University of Cape Town Press.

Statistics South Africa (20II): Census municipal report, North West Province. Report No. 03-0I64.

Stloukal, L 200I. "Rural population ageing in poorer countries: Possible implications for rural development." Quarterly Journal of the International Institute on Ageing I I, (4): 16-23.

Tatara, T (1997): The national elder abuse incidence study. New York, NY: Human Services Press.

Tibaijuka, A (2008): State of the World's cities report. New York: UN-HABITAT.

United Nations Population Division (2002): World Population Prospects, the 2002 Revision: Highlights. New York: United Nations Population Division.

Urassa, M.J., Boerma, T., Ng'weshami, J.Z.L., Isingo, R., Schapnik, D \& Kumogola, Y 1997.
"Orphanhood, child fostering and the AIDS epidemic in rural Tanzania". In K, AwusaboAsare, J.T. Boerma \& B. Zaba (eds). Evidence of the Socio-demographic impact of AIDS in Africa. Health Transition Review, supl.7 (2), National University of Australia, Canberra, pp. I4I-I54.

Weeks, L., Richards,J., Nilsson,T., Kozma, A \& Bryanton, D 2005. "A gendered analysis of the abuse of older adults: Evidence from professionals." Journal of Elder Abuse and Neglect 16, (2): I-I5.

World Health Organisation (2002): Abuse of the elderly. Geneva: World Health Organization.

World Health Organization (2008): A Global response to elder abuse and neglect. Geneva: World Health Organization.

Wu, L., Shen, M., Chen, H., Zhang, T., Cao, Z., Xiang, $\mathrm{H}$ \& Wang, $Y$ 2013. "The relationship between elder mistreatment and suicidal ideation in rural older adults in china." American Journal of Geriatrics and Psychiatry 2I, (10): 1020-1028. 